\title{
Assessment of changes in smile after rapid maxillary expansion
}

\author{
Ana Paula Morales Cobra de Carvalho', Fernanda Cavicchioli Goldenberg' ${ }^{2}$, Fernanda Angelieri ${ }^{3}$, \\ Danilo Furquim Siqueira ${ }^{4}$, Silvana Bommarito ${ }^{5}$, Marco Antonio Scanavini ${ }^{6}$, Lylian Kazumi Kanashiro ${ }^{7}$
}

Introduction: This study evaluated changes in the smile characteristics of patients with maxillary constriction submitted to rapid maxillary expansion (RME). Methods: The sample consisted of 81 extraoral photographs of maximum smile of 27 patients with mean age of 10 years, before expansion and 3 and 6 months after fixation of the expanding screw. The photographs were analyzed on the software Cef X 2001, with achievement of the following measurements: Transverse smile area, buccal corridors, exposure of maxillary incisors, gingival exposure of maxillary incisors, smile height, upper and lower lip thickness, smile symmetry and smile arch. Statistical analysis was performed by analysis of variance (ANOVA), at a significance level of $5 \%$. Results: RME promoted statistically significant increase in the transverse smile dimension and exposure of maxillary central and lateral incisors; maintenance of right and left side smile symmetry and of the lack of parallelism between the curvature of the maxillary incisal edges and lower lip border. Conclusions: RME was beneficial for the smile esthetics with the increase of the transverse smile dimension and exposure of maxillary central and lateral incisors.

Keywords: Orthodontics. Smile. Interceptive orthodontics.

Introdução: esse estudo avaliou as alterações das características do sorriso de pacientes com atresia maxilar submetidos à expansão rápida da maxila (ERM). Métodos: a amostra consistiu de 81 fotografias extrabucais do sorriso máximo de 27 pacientes, com idade média de 10 anos, antes da expansão e aos três e seis meses após a fixação do parafuso expansor. As análises das fotografias foram realizadas por meio do programa Cef X 2001, e as seguintes medidas foram analisadas: dimensão transversal do sorriso, corredores bucais, quantidade de exposição dos incisivos superiores, exposição gengival dos incisivos superiores, altura do sorriso, espessuras dos lábios superior e inferior, simetria e arco do sorriso. As alterações no sorriso durante as diferentes fases foram avaliadas por meio da análise de variância (ANOVA), seguida pelo teste de comparações múltiplas de Bonferroni, com nível de significância de 5\%. Resultados: a ERM promoveu aumento estatisticamente significativo da dimensão transversal do sorriso e da quantidade de exposição dos incisivos centrais e laterais superiores; manutenção da simetria entre os lados direito e esquerdo e da falta de paralelismo entre a curvatura das bordas dos incisivos superiores e a do lábio inferior. Conclusão: a ERM beneficiou a estética do sorriso com o aumento da dimensão transversal do sorriso e da quantidade de exposição dos incisivos centrais e laterais superiores.

Palavras-chave: Ortodontia. Sorriso. Ortodontia interceptora.

${ }^{1}$ MSc in Orthodontics, Methodist University of São Paulo (UMESP).

${ }^{2} \mathrm{PhD}$ in Sciences, UNIFESP.

${ }^{3}$ Associate professor of the post-graduation course in Orthodontics, Methodist University of São Paulo.

${ }^{4}$ Professor of graduation, specialization and MSc courses, Sacred Heart University (USC).

${ }^{5}$ Associate Professor, Department of Speech Therapy, UNIFESP/EPM. Professor in charge of the Oral Motricity Department, UNIFESP/EPM.

${ }^{6}$ Head of graduate program in Dentistry, Methodist University of São Paulo.

${ }^{6} \mathrm{MSc}$ and $\mathrm{PhD}$ in Orthodontics, FOUSP. Professor of Orthodontics, FOUSP.
How to cite this article: Carvalho APMC, Goldenberg FC, Angelieri F, Siqueira DF, Bommarito S, Scanavini MA, Kanashiro LK. Assessment of changes in smile after rapid maxillary expansion. Dental Press J Orthod. 2012 Sept-Oct;17(5):94-101.

Submitted: November 07, 2011 - Revised and accepted: Juny 28, 2012.

" The authors report no commercial, proprietary or financial interest in the products or companies described in this article.

" Patients displayed in this article previously approved the use of their facial and intraoral photographs.

Contact address: Ana Paula M. C. de Carvalho

Rua Cantagalo, 630, ap. 102 - Tatuapé

Zip code: 03.319-000 - São Paulo/SP, Brazil

E-mail: anapaula1007@hotmail.com 


\section{INTRODUCTION}

Recent years have seen an increasing emphasis given to face and smile esthetics by dental professionals and patients alike.

Smile analysis is part of a broader facial morphology analysis and allows dentists to recognize positive and negative elements in each patient's smile. The literature suggests that some characteristics, such as the following, should be assessed: Smile line, ${ }^{1}$ curvature of the upper and lower lip,,$^{1-5}$ parallelism between the curvature of the incisal edges and the lower lip, ${ }^{2,6,7}$ transverse dimension, smile height, ${ }^{8}$ upper and lower lip thickness, ${ }^{1}$ lip symmetry, ${ }^{1}$ buccal corridor ${ }^{1,4,8}$ extent of elevation of the upper lip, ${ }^{1}$ amount of exposure of central ${ }^{1}$ and lateral ${ }^{1}$ incisors, and gingival display. ${ }^{2,8,9,10}$

Depending on the type of malocclusion, patient's facial pattern and mechanics adopted, orthodontic treatment can prove either beneficial or harmful to smile esthetics. Thus, it is reasonable to regard facial analysis as an important tool for diagnosis and orthodontic treatment planning.

Maxillary constriction is very common in orthodontic patients in the mixed dentition stage, which can affect occlusion, facial development and smile esthetics. Rapid maxillary expansion (RME) is a treatment often indicated for correction of transverse skeletal deficiency by means of maxillary expansion appliances. ${ }^{6,12,21,22}$

Based on the belief that it is important to learn in advance about the effects of orthodontic mechanics on smile esthetics with a view to benefitting patients, this study aimed to verify the possible changes in smile characteristics after RME in patients with mixed dentition.

\section{MATERIAL AND METHODS}

\section{Sample}

The sample consisted of 81 extraoral photographs of maximum smiles of 27 patients from the Department of the Graduate Program in Orthodontics at UMESP, mean age 10 years and 3 months (between 8 and 11 years), 15 women and 12 men with maxillary constriction, after RME. The following patient inclusion criteria were used: Presence of posterior unilateral or bilateral crossbite requiring maxillary expansion as the first phase of orthodontic treatment; mixed dentition with complete eruption of permanent first molars and incisors; absence of congenital syndromes or deformities; no prior orthodontic treatment, mutilations or dental agenesis. This study was approved by the UMESP Ethics Committee (file \#164761).

\section{Methods \\ Rapid maxillary expansion}

The appliance used to perform RME was a modified ${ }^{11}$ Hyrax type expander, which was attached to the patient's arch by cementing bands with glass ionomer and bonding metal stop rests to the buccal and palatal surfaces of the deciduous canines using composite resin (Fig 1).

The activation protocol was as follows: ${ }^{12} \mathrm{~A}$ full turn applied by the researcher immediately after placement of the appliance, $2 / 4$ turn once a day applied by the patient's legal guardian until the desired expansion overcorrection was achieved (palatal cusp of the upper first permanent molar occluding with the buccal cusp of the first lower permanent molar). As soon as activation was completed, the appliance was kept in place for retention for 3 months. ${ }^{12}$ Thereafter, the expander was removed and an acrylic plate was used for retention for 3 months.

\section{Photographs}

In order to evaluate the smiles, standardized frontal photographs of the patients' faces were taken at the following times:

» $\mathrm{T}_{1}$ : Before placing the expander

» $\mathrm{T}_{2}: 3$ months after completing expansion

» $\mathrm{T}_{3}$ : Six months after completing expansion (3 months after removal of the expander).

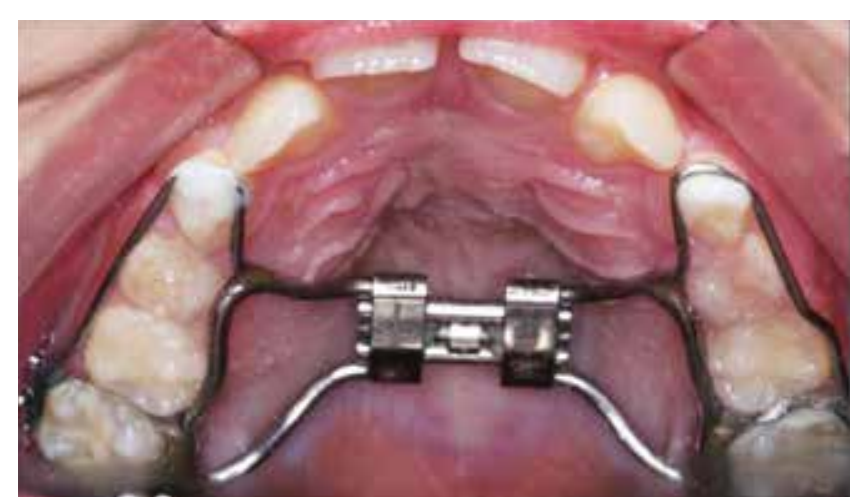

Figure 1 - Modified Hyrax expander. 
All photographs were taken in the same room to ensure uninterrupted lighting, with the same camera (Canon EOS Rebel XT) and focal length, which was achieved by attaching the camera to a stabilizing mount specially designed for this purpose..$^{10,13}$

The patients were instructed to stand upright and position their heads in front view one meter away from the camera. Oriented Natural Head Position was adopted as it is considered reliably reproducible in literature. ${ }^{7,14-17}$ The cephalostat had a millimeter ruler attached to its horizontal structure and was adapted to the external auditory canal of the patients for head stability. The ruler was incorporated into the photographs to assist in calibrating all linear measurements.

To standardize the smile at the three study times, patients were instructed to produce a posed, voluntary, self-induced smile, which can be repeated at different times as it involves maximum lip expansion. ${ }^{1}$

\section{Smile analysis}

To calibrate the size of the photographic image to a real dimension, all digital images were imported into Cef X 2001 (CDT) software. This program provides a tool to measure the virtual distance of $1 \mathrm{~cm}$ viewed on the millimeter ruler (actual value) for each photograph. The digital images of the patients were then loaded into Adobe Photoshop 7.0 (Adobe Systems) and by manipulating the image size tool and using the percentage value of magnification previously obtained, each image was converted to their real size.

\section{Smile analysis measurements}

Once converted to their real size, the images were imported into the Cef X 2001 program for analyzing the smiles at the three different times. Some of the measurements required the construction of the following reference lines (Fig 2):

1) Right and left labial commissures: Horizontal line joining the right (RLC) and left (LLC) labial commissures.

2) Smile center: Geometric center of the rectangle formed by two lines parallel to the line of the rima oris and tangent to the uppermost points on the edge of the upper lip and the lowermost points on the edge of the lower lip, in addition to 2 perpendicular lines passing through RLC and LLC.
3) Vertical line at the center of the smile: perpendicular to the line of the rima oris, passing through the center of the smile.

4) Horizontal line at the center of the smile: parallel to the line of the rima oris, passing through the center of the smile.

5) Facial midline: Line passing through the lip philtrum.

After establishing the reference lines on the images of the smiles of each patient at the three different times, linear measurements were obtained with Cef $\mathrm{X} 2001$ and used in analyzing the smile in the horizontal and vertical directions as well as its symmetry:

\section{Horizontal evaluation of the smile (Fig 3)}

1) Transverse dimension of the smile: Distance between the right and left labial commissures (RLC and LLC).

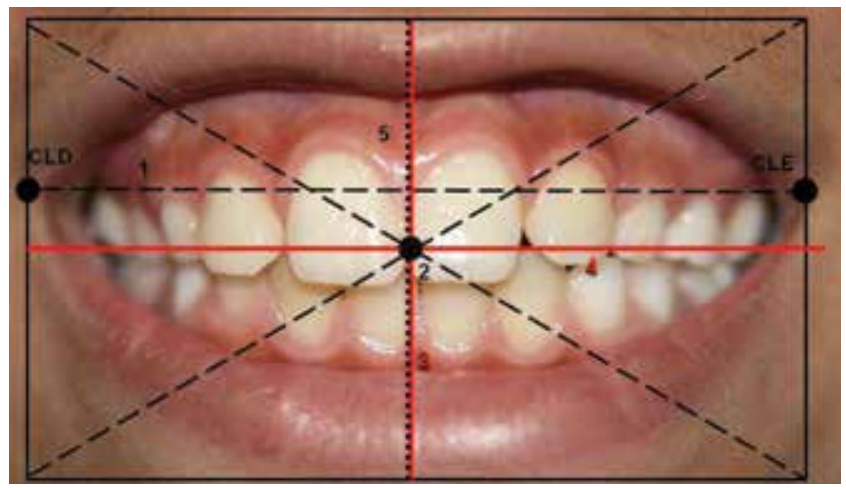

Figure 2 - Reference lines for smile analysis.

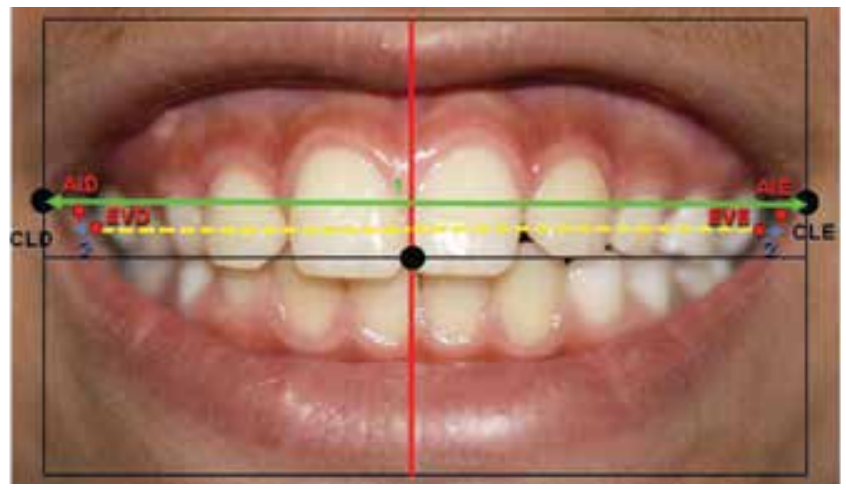

Figure 3 - Horizontal measurements of the smile: Transverse dimension of the smile, and right and left buccal corridors. 
2) Right and left buccal corridors: Distances between the right (RBE) and left (LBE) buccal extremes and their respective inner portions of the labial commissures, i.e., right internal angle (RIA) and left internal angle (LIA), orthogonally to the vertical smile.

\section{Vertical smile evaluation (Figs 4 and 5)}

1) Incisor exposure: Distances between the midpoints on the incisal edges of central incisors and

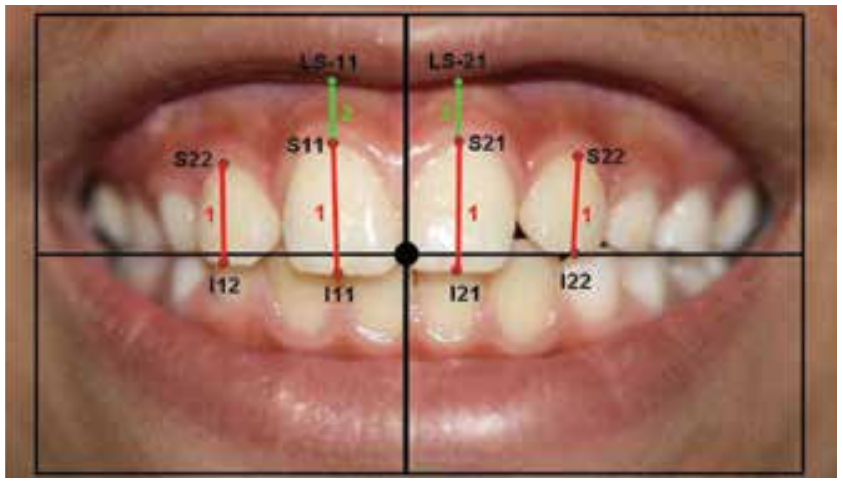

Figure 4 - Vertical measurements of the smile: Incisor exposure and gingival display.

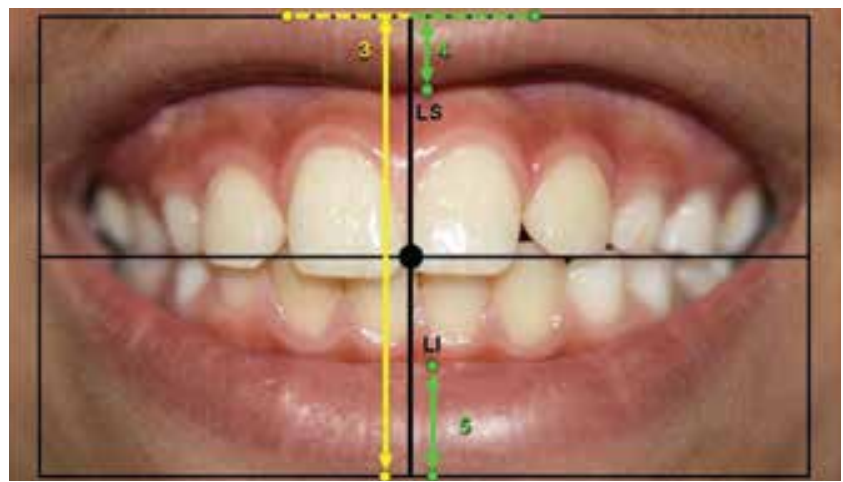

Figure 5 - Vertical measurements of the smile: Smile height and upper and lower lip thickness.

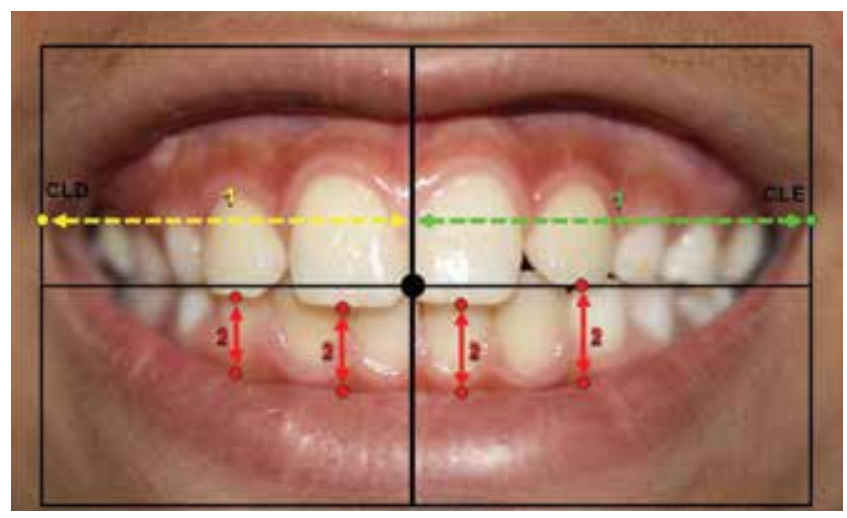

Figure 6 - Smile symmetry: Right and left sides, and smile arch. right and left upper laterals (I11, I21, I12, I22) and their respective uppermost points at the intersection with the long axis of these teeth.

2) Gingival display: Distances between the cervical points of the right and left central incisors (Cll and C21) and their respective points of intersection between the lower edge of the upper lip and the long axes of these teeth (UL-11 and UL-21).

3) Smile height: Distance between the uppermost points on the upper edge of the upper lip and the lowermost points on the lower edge of the lower lip, projected onto the vertical line at the center of the smile.

4) Upper lip thickness: Distance between the lower edge of the upper lip (UL) and the Stomion, projected onto the vertical line at the center of the smile.

5) Lower lip thickness: Distance between the upper edge of the lower lip (LL) and the Stomion, projected onto the vertical line at the center of the smile.

\section{Symmetry assessment and smile arch (Fig 6)}

1) Right and left sides of the smile: Distances between the left and right labial commissures (LLC and RLC) and the facial midline

2) Smile arch: Comparison of the distances between the edges of the upper incisors and the lower lip, projected onto the vertical line of the smile.

\section{Statistical analysis}

To evaluate method error all measurements of one of the smile photographs of each patient were repeated 30 days after the first measurement. Random error was verified using Dahlberg's formula ${ }^{18}$ and systematic error by Intraclass Correlation. ${ }^{19}$

To evaluate changes in the characteristics of the smile during the different phases, analysis of variance (ANOVA) was employed at a significance level of $0.05(\alpha=5 \%)$. Variables that showed statistically significant differences were tested using Bonferroni's multiple comparisons test ${ }^{19}$ to assess at what time(s) the changes occurred.

To verify smile symmetry, the measurements from the incisors to the lower lip were compared using analysis of variance (ANOVA) with repeated measurements 
of two factors, assuming a symmetrical component correlation matrix, ${ }^{20}$ followed by Bonferroni's ${ }^{19}$ multiple comparisons test to compare pairs of interest.

\section{RESULTS}

\section{Method error}

All measurements were found to be very consistent since the intraclass correlation values were close to 1 , and random error could be considered acceptable given its low values in light of the magnitude of the measurements $($ mean $=0.367 \mathrm{~mm}, \mathrm{SD}=0.192)$.

\section{Smile analysis}

\section{Horizontal evaluation of the smile (Table 1)}

The transverse dimension of the smile and the right buccal corridor showed statistically significant differences during the study period $(p<0.05)$. It was found that the transverse distance of the smile had a statistically significant increase from time $T_{1}$ to times $T_{2}$ and $T_{3}$, and the right buccal corridor experienced a statistically significant decrease from time $\mathrm{T}_{1}$ to times $\mathrm{T}_{2}$ and $\mathrm{T}_{3}$.

\section{Vertical evaluation of the smile}

The amount of exposure of the upper incisors was the only variable to exhibit a statistically significant increase $(\mathrm{p}<0.05)$ between $\mathrm{T}_{1}$ and $\mathrm{T}_{2}$, and $\mathrm{T}_{1}$ and $\mathrm{T}_{3}$. Gingival display, smile height and thickness of the upper and lower lips did not show any statistically significant changes during the study period ( $p>0.05)$.

\section{Symmetry assessment and smile arch}

As regards the smile arch, no statistically significant difference was found in the distances of the incisal edges and the lower lip at different times. In comparing these distances according to place and time, there were statistically significant differences in terms of place $(\mathrm{p}<0.05)$. The distance between the incisal edge of the right lateral incisor and lower lip was statistically higher than those of the right and left central incisors. This behavior was kept at the three different times $(\mathrm{p}>0.05)$, i.e., the line formed by the incisal edges of the upper incisors was not parallel to the lower lip during treatment.

The smile showed symmetry between the left and right sides at all times as there was no statistically significant change in place $(\mathrm{p}=0.852)$. However, a statistically significant increase was noted in the measurements of the right side of the smile during treatment between time $\mathrm{T}_{1}$ and the other treatment times $\left(\mathrm{T}_{2}\right.$ and $\left.\mathrm{T}_{3}\right)$.

Table 1 - Comparison of changes in horizontal and vertical characteristics of the smile: ANOVA and Bonferroni test of multiple comparisons.

\begin{tabular}{|c|c|c|c|c|}
\hline & $\begin{array}{l}\left.\text { Initial ( } T_{1}\right) \\
\text { Mean + SD }\end{array}$ & $\begin{array}{c}3 \text { months }\left(\mathbf{T}_{2}\right) \\
\text { Mean + SD }\end{array}$ & $\begin{array}{c}6 \text { months }\left(T_{3}\right) \\
\text { Mean + SD }\end{array}$ & $\mathbf{p}$ \\
\hline \multicolumn{5}{|l|}{ Horizontal evaluation } \\
\hline Transverse dimension & $61.91 \pm 4.16^{\mathrm{a}}$ & $63.76 \pm 4.85^{b}$ & $64.64 \pm 4.99^{b}$ & $0.001^{\star}$ \\
\hline Right buccal corridor & $4.83 \pm 1.95^{\mathrm{a}}$ & $3.55 \pm 1.73^{b}$ & $3.70 \pm 1.48^{b}$ & $0.001^{*}$ \\
\hline Left buccal corridor & $4.49 \pm 1.91$ & $3.77 \pm 1.41$ & $4.47 \pm 1.52$ & 0.102 \\
\hline \multicolumn{5}{|l|}{ Vertical evaluation } \\
\hline Tooth 11 exposition & $8.09 \pm 1.68^{\mathrm{a}}$ & $9.03 \pm 1.61^{b}$ & $9.05 \pm 1.50^{b}$ & $<0.001^{\star}$ \\
\hline Tooth 21 exposition & $7.88 \pm 1.91^{\mathrm{a}}$ & $8.91 \pm 1.44^{b}$ & $8.85 \pm 1.47^{b}$ & $0.003^{\star}$ \\
\hline Tooth 12 exposition & $5.76 \pm 1.45^{\mathrm{a}}$ & $6.38 \pm 1.52^{b}$ & $6.39 \pm 1.34^{b}$ & $0.002^{\star}$ \\
\hline Tooth 22 exposition & $5.84 \pm 1.58^{\mathrm{a}}$ & $6.72 \pm 1.24^{b}$ & $6.52 \pm 1.06^{\mathrm{a} ; \mathrm{b}}$ & $0.002^{\star}$ \\
\hline Tooth 11 gingival display & $0.53 \pm 1.03$ & $0.68 \pm 0.93$ & $0.55 \pm 0.67$ & 0.684 \\
\hline Tooth 21 gingival display & $0.54 \pm 1.14$ & $0.71 \pm 0.89$ & $0.66 \pm 0.91$ & 0.554 \\
\hline Smile height & $25.90 \pm 6.07$ & $27.28 \pm 4.78$ & $27.01 \pm 4.92$ & 0.362 \\
\hline Upper lip thickness & $5.49 \pm 1.75$ & $5.81 \pm 1.80$ & $5.88 \pm 1.84$ & 0.409 \\
\hline Lower lip thickness & $8.05 \pm 1.55$ & $8.38 \pm 1.02$ & $8.50 \pm 1.31$ & 0.249 \\
\hline
\end{tabular}

* Statistically significant $-p<0.05$ (ANOVA).

a:b: Different superscript letters mean statistically significant differences, according to the smile characteristics (Bonferroni multiple comparisons). 
Table 2 - Comparison of changes in the characteristics of smile symmetry according to the site and time: ANOVA and Bonferroni multiple comparisons.

\begin{tabular}{|c|c|c|c|c|c|}
\hline & \multirow{3}{*}{$\begin{array}{c}\text { Smile symmetry } \\
\text { evaluation }\end{array}$} & \multicolumn{3}{|c|}{ Time } & \multirow{3}{*}{$\mathbf{p}$} \\
\hline & & Initial ( $\left.\mathbf{T}_{\mathbf{1}}\right)$ & 3 months $\left(T_{2}\right)$ & 6 months $\left(T_{3}\right)$ & \\
\hline & & Mean $(\mathrm{mm}) \pm \mathbf{S D}$ & Mean $(\mathrm{mm}) \pm \mathrm{SD}$ & Mean $(\mathbf{m m}) \pm$ SD & \\
\hline \multirow{8}{*}{ 픔 } & Tooth 11 incisal - LL & $3.34 \pm 2.29^{a}$ & $3.73 \pm 2.84^{a}$ & $3.53 \pm 2.79^{a}$ & 0.562 \\
\hline & Tooth 21 incisal - LL & $3.17 \pm 2.45^{\mathrm{a}}$ & $3.56 \pm 2.78^{a}$ & $3.54 \pm 2.94^{\mathrm{a}}$ & 0.544 \\
\hline & Tooth 12 incisal - LL & $4.08 \pm 2.64^{b}$ & $4.57 \pm 2.99^{b}$ & $4.46 \pm 2.74^{b}$ & 0.505 \\
\hline & Tooth 22 incisal - LL & $3.64 \pm 2.69^{a . b}$ & $3.84 \pm 2.94^{a . b}$ & $4.03 \pm 2.74^{a . b}$ & 0.683 \\
\hline & & \multicolumn{4}{|c|}{$p=0.001^{\star}$} \\
\hline & Right side of smile & $30.62 \pm 2.72^{a}$ & $32.13 \pm 3.45^{b}$ & $33.01 \pm 2.59^{b}$ & $<0.001^{\star}$ \\
\hline & \multirow[t]{2}{*}{ Left side of smile } & $31.44 \pm 2.20$ & $32.29 \pm 3.36$ & $32.22 \pm 3.50$ & 0.328 \\
\hline & & \multicolumn{4}{|c|}{$p=0.852$} \\
\hline
\end{tabular}

* Statistically significant $-p<0.05$ (ANOVA).

a;b: Different superscript letters mean statistically significant differences (Bonferroni multiple comparisons).

\section{DISCUSSION}

While esthetics is one of the goals of the orthodontist and a paramount issue for most patients seeking orthodontic treatment, the importance of an objective analysis of the smile is still underestimate in diagnosing, planning and monitoring the results of the mechanics applied. .,4, $^{20}$ This study aimed to assess changes in the smile of patients undergoing RME, a technique which has been well established in literature. It consists in expanding the maxilla by splitting the palate in the region of the sutures to correct maxillary constriction and posterior crossbites. ${ }^{6,21,22}$

According to the literature, smile evaluations can be conducted in either subjective or objective manner. ${ }^{3,4,10,23,24}$ An attempt was made to focus on some features considered important and objective in analyzing the esthetics of the smile so that tangible results could be achieved unaffected by the researcher's personal or subjective interpretation.

\section{Horizontal aspect of the smile}

The dimension of the buccal corridor is seen as one of the characteristics that influence smile esthetics. ${ }^{1,4,25}$ According to some authors, ${ }^{4}$ the smaller the corridor, the better the esthetics. Although this study employed RME as its key mechanics, which might lead to expectations of a significant decrease in the buccal corridor, there was a statistically significant decrease only in the right buccal corridor, between $\mathrm{T}_{1}$ and $\mathrm{T}_{2}$, and $\mathrm{T}_{1}$ and $\mathrm{T}_{3}$.
However, changes of $1.29 \mathrm{~mm}\left(\mathrm{~T}_{1}-\mathrm{T}_{2}\right)$ and $1.13 \mathrm{~mm}\left(\mathrm{~T}_{1}-\mathrm{T}_{3}\right)$ do not seem to be clinically significant in view of the amount of expansion achieved (mean $5.96 \mathrm{~mm}$ ).

The increased bone tissue support produced by expanding the dental arches also affects soft tissues. ${ }^{4}$ Thus, the expected buccal corridor reduction effect may have been minimized by an increase in the transverse dimension of the smile caused by expansion of the soft tissues, which occurred concurrently with RME. The transverse dimension of the smile, measured between the labial commissures, showed a statistically significant increase between baseline and 3 months, and between baseline and 6 months. However, in the retention phase (3-6 months) the transverse dimension of the smile remained stable.

Although further studies are needed, the difference in the responses of the right and left buccal corridors could be explained by a difference in muscle tone between the two sides due to asymmetric chewing (predominance of one side over the other) in many patients.

\section{Vertical aspect of the smile}

This study showed that RME did not induce significant changes in the soft tissues in the vertical direction. Smile height and thickness of the upper and lower lips showed no statistically significant differences during the treatment. Thus, the thicker the lips, the greater the improvement in smile esthetics. ${ }^{26}$ 
Central and lateral incisor's crown exposure was greater 3 and 6 months after expansion completion, compared to $\mathrm{T}_{1}$, with statistically significant differences, which corroborates the work of Ackerman and Ackerman. ${ }^{2}$ This effect may have been produced by the anterior and inferior displacement of point $A$, found by many researchers after this procedure, ${ }^{12,27-30}$ since there was no change in smile height or upper lip thickness, which might influence this measure. Increases in the amount of central and lateral incisor exposure can also be linked to improvement in some aspects given an increase in the perimeter of the dental arch brought about by expansion. To illustrate this finding, one can mention the dental arch form, the spontaneous correction of crowding and of lateral incisor inclination, which were initially influenced by the intra-bone canines. Regarding the possible influence of growth on this result, the authors believe that this factor had little or no influence on the increased exposure of the incisors, whereas this increase occurred only after palate splitting (between $\mathrm{T}_{1}$ and $\mathrm{T}_{2}$ ) and this change remained between the subsequent periods $\left(\mathrm{T}_{2}\right.$ and $\mathrm{T}_{3}$ ) (Table 1 ). Thus, this study shows that RME contributed to increased smile esthetics since ideally there should be total or partial incisor exposure, i.e., the greater the incisor exposure, the more enhanced the esthetics. ${ }^{1,8}$ Exposures of less than $75 \%$ of the incisor crown are considered non-esthetic. ${ }^{4}$

Another factor considered relevant to the analysis of the smile is the amount of gingival display in the region of maxillary central incisors. ${ }^{2,4,8,9,28}$ According to some authors, the lower the gingival display, the more enhanced is smile esthetics. Although a slight tendency towards increased display of the gingival region of the central incisors could be noticed, especially between $\mathrm{T}_{1}$ and $\mathrm{T}_{2}$, the differences were not statistically significant throughout the treatment and therefore did not influence smile esthetics in this sample.

\section{Symmetry and smile arch}

Alterations were found in the measurements of the right side of the smile during treatment, with a statistically significant increase between $\mathrm{T}_{1}$ and $\mathrm{T}_{2}$, and $\mathrm{T}_{1}$ and $\mathrm{T}_{3}$. However, smile symmetry was preserved between the left and right sides at all times studied $\left(\mathrm{T}_{1}, \mathrm{~T}_{2}\right.$ and $\left.\mathrm{T}_{3}\right)$. Another important aspect of smile esthetics is the relationship between the curvature of the incisal edges of maxillary anterior teeth and the curvature of the lower lip, called smile arch. The smile arch is considered esthetic when there is parallelism between these two reference lines. ${ }^{5,924}$ To verify parallelism between the curvatures, measurements were made between the incisal edges of upper incisors and the corresponding points on the upper edge of the lower lip, and these measurements were then compared. The greater the similarity, the greater the perceived parallelism.

The distances between the incisal edges and the lower lip showed, on average, the same behavior throughout the treatment. The line formed by the incisal edges of the maxillary incisors was not parallel to the lower lip during treatment, whereas the distance between the incisal edge of the right lateral incisor and the lower lip was statistically higher than those of the right and left central incisors.

Given that orthodontic treatment can modify the smile, analyzing it is of utmost importance for diagnosis and planning, and to enable professionals to pursue and achieve a more esthetic smile. The author of this study therefore believes that learning about the effects of orthodontic mechanics on the smile by means of continued scientific endeavors can be very fruitful as it allows a prognosis to be set prior to starting the treatment, which can benefit the patient's facial esthetic. This study showed that RME helped to improve the esthetics of the smile. It should be emphasized, however, that other factors such as type of malocclusion and facial pattern also influence the patient's smile esthetics. Therefore, depending on the nature of the patient's condition, RME alone may not be sufficient to improve smile esthetics.

\section{CONCLUSIONS}

According to the results, it is reasonable to conclude that RME enabled:

A statistically significant increase in the transverse dimension of the smile, while the buccal corridor remained virtually unchanged.

»An increase in the amount of exposure of the upper incisors. However, the smile height and the thickness of the upper and lower lips remained stable.

" Symmetry between the right and left sides was preserved, as well as a lack of parallelism between the curvature of the edges of the upper incisors and the curvature of the lower lip. 


\section{REFERENCES}

1. Sabri R. The eight components of a balanced smile. J Clin Orthod. 2005;39(3):155-67.

2. Ackerman MB, Ackerman JL. Smile analysis and design in the digital era. J Clin Orthod. 2002;36(4):231-6.

3. Sarver DM. The importance of incisor positioning in the esthetic smile: the smile arc. Am J Orthod Dentofacial Orthop. 2001;120(2):98-111.

4. Sarver DM, Ackerman MB. Dynamic smile visualization and quantification: part 2. Evolution of the concept and dynamic records for smile capture. Am J Orthod Dentofac Orthop. 2003;124(2):116-27

5. Wong NKC, Kassim AA, Foong KWC. Analysis of esthetic smiles by using computer vision techniques. Am J Orthod Dentofac Orthop. 2005;128:404-11.

6. Haas AJ. Palatal expansion: Just the beginning of dentofacial orthopedics. Am J Orthod. 1970;57(3):219-55.

7. Martins LF. Análise fotométrica em normas frontal de adultos brasileiros, leucodermas, não tratados ortodonticamente, classificados pela estética facial [Dissertação]. São Bernardo do Campo (SP): Universidade Metodista de São Paulo, Faculdade de Odontologia; 2002

8. Moskowitz ME, Nayyar A. Determinants of dental esthetics: a rationale for smile analysis and treatment. Comp Cont Ed Dent. 1995;16:1164-86.

9. Basting RT, Trindade RS, Flório FM. Comparative study of smile analysis by subjective and computerized methods. Oper Dent 2006;31(6):652-9.

10. Sarver DM, Ackerman MB. Dynamic smile visualization and quantification: part 1. Evolution of the concept and dynamic records for smile capture. Am J Orthod Dentofac Orthop. 2003;124(1):4-12

11. Cohen M, Silverman E. A new and simple palate splitting device. J Clin Orthod. 1973;7(6):368-9.

12. Haas AJ. Rapid expansion of the maxillary dental arch and nasal cavity by opening the midpalatal suture. Angle Orthod. 1960;31(2):73-90.

13. Trevisan F. Análise Fotogramétrica e subjetiva do perfil facial de jovens brasileiros, leucodermas, com oclusão normal [Dissertação]. São Bernardo do Campo (SP): Universidade Metodista de São Paulo, Faculdade de Odontologia; 2003.

14. Chui CS, Clark RKF. Reproducibility of natural head position. J Dent. 1991;19:130-1.

15. Lundström A. A comparison between estimated and registered natural head posture. Eur J Orthod. 1991;13:59-64.

16. Strauss RA. Variability of facial photographs for use in treatment planning for orthodontic and orthognatic surgery. Int J Adult Orthod Orthog Surg. 1997;12(3):197-203.
17. Viazis AD. Avaliação do tecido mole. In: Viazis AD. Atlas de Ortodontia: Princípios e aplicações clínicas. São Paulo (SP): Ed. Santos; 1996. p. 49-57.

18. Dahlberg G. Statistical methods for medical and biological students. New York (NY): Interscience; 1940.

19. Neter J, Kutner MH, Nachtsheim CJ, Wasserman W. Applied Linear Statistical Models. 4th ed. Chicago (IL): Richard D. Irwing; 1996.

20. Singer JM, Andrade DF. Analysis of longitudinal data. In: Handbook of Statistics: Bio-Environmental and Public Health Statistics. Amsterdam: PK Sen and CR Rao; 2000. p. $115-60$.

21. Geran RG, McNamara Jr JA, Baccetti T, Shapiro LM. A prospective long term study on the effects of rapid maxillary expansion in the early mixed dentition. Am J Orthod Dentofac Orthop. 2006;129(5):631-40.

22. Haas AJ. The treatment of maxillary deficiency by opening midpalatal suture. Angle Orthod. 1965;35(3):200-17.

23. Berger JL, Pangrazio-Kulbersh V, Thomas BW, Kaczynski R. Photographic analysis of facial changes associated with maxillary expansion. Am J Orthod Dentofac Orthop. 1999;116:563-71.

24. Sarver DM, Ackerman JL. Orthodontics about face: the re-emergence of the esthetic paradigm. Am J Orthod Dentofac Orthop. 2000;117(5):575-6.

25. Ritter DE, Gandini Jr LG, Pinto AS. Analysis of the smile photograph. World J Orthod. 2006;7(3):279-85

26. McNamara Jr AJ, Ackerman MB, Baccetti T. Hard and soft tissue contributions to the esthetics of the posed smile in growing patients seeking orthodontic treatment. Am J Orthod Dentofac Orthop. 2008:133(4):491-500.

27. Brandt S. Interview with Dr. Andrew J. Haas. J Clin Orthod. 1973;7(4):227-45.

28. Chang $C$, Font $B$. Skeletal and dental changes in the sagittal, vertical, and transverse dimensions after rapid palatal expansion. Am J Orthod Dentofac Orthop. 2004;126:569-75

29. Silva Filho OG, Villas-Boas MC, Capelozza Filho L. Rapid maxillary expansion in the primary and mixed dentitions: a cephalometric evaluation. Am J Orthod Dentofac Orthop. 1991;100:171-81.

30. Wertz RA. Skeletal and dental changes accompanying rapid midpalatal suture opening. Am J Orthod. 1970;58(1):41-61. 